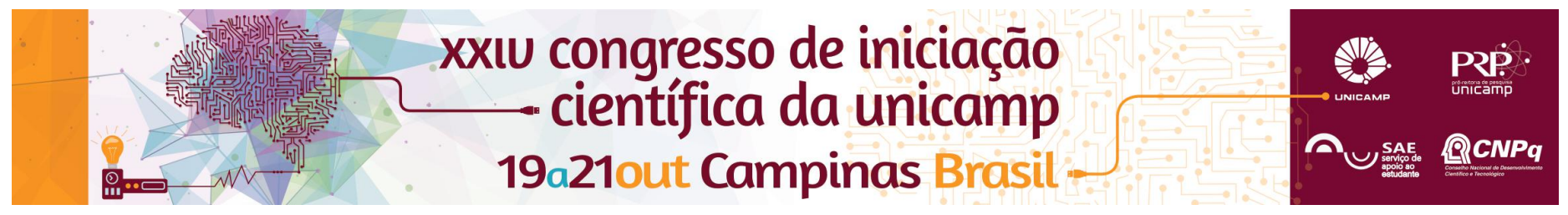

\title{
Análise da Contribuição da Resistência do Subleito no Dimensionamento de Pavimentos Flexíveis
}

\section{Jéssica Nunes Pierazolli*}

\section{Resumo}

Neste trabalho, uma série de 120 valores de CBR, obtidos num segmento rodoviário de extensão total de $13,22 \mathrm{~km}$, foi trabalhada empregando-se diferentes agrupamentos dos valores e submetendo-os a procedimentos, tais como aqueles usualmente recomendados pelo DNIT e pelo DER-SP, para a determinação do valor característico da capacidade de suporte do subleito. Adicionalmente, aplicou-se um procedimento preconizado pela AASHTO denominado "Método das Diferenças Acumuladas". Foram analisados então os efeitos que estas alterações impõem ao valor característico de projeto e, consequentemente, à durabilidade e aos custos de construção do segmento.

\section{Palavras-chave \\ Pavimento, Dimensionamento, Resistência do Subleito}

\section{Introdução}

No dimensionamento de pavimentos, a capacidade de suporte do solo do subleito é fundamental para a definição das espessuras das camadas e para a previsão de seu futuro desempenho. Normalmente são realizadas várias sondagens ao longo do traçado para caracterizar o solo existente e contribuir nos projetos de pavimentação e de terraplenagem. Entre os parâmetros a serem determinados na caracterização está a capacidade de suporte do subleito, que pode ser representada pelo tradicional índice CBR (California Bearing Ratio) ou pelo módulo de resiliência MR. A definição do valor característico do CBR, ou seja, o CBR representativo de cada segmento do subleito para projeto de pavimentação, pode ser realizada através de vários procedimentos, que se diferenciam principalmente pelo tratamento estatístico que propõem.

\section{Resultados, Discussão e Conclusões}

Um tratamento estatístico adequado do valor característico do CBR oferece ao projetista condições para que ele execute um dimensionamento apropriado ao segmento rodoviário objeto de projeto. A qualidade do tratamento é tanto melhor quanto menor o risco de este conferir ao trecho um sub ou superdimensionamento.

Quanto ao subleito, segundo Balbo (2007), os esforços impostos sobre sua superfície serão aliviados em sua profundidade. Nos estratos superiores os esforços solicitantes atuam com maior magnitude.

De acordo com Critério do CBR para dimensionamento, para um menor valor de CBR, determina-se espessuras maiores sobre o subleito, para sua proteção. Desta forma, obtendo-se o valor representativo de CBR a partir de um tratamento que perturbe o mesmo mais sensivelmente na presença valores baixos de $\mathrm{CBR}$, isolados e pontuais, tende-se à determinação de espessuras superdimensionadas das camadas do pavimento para $\mathrm{O}$ trecho. $\mathrm{O}$ superdimensionamento, por sua vez, ocasionaria um impacto patente sobre os custos de construção do pavimento.

Partindo dessa premissa, buscou-se primeiramente nesta pesquisa determinar o método menos susceptível a um dimensionamento inadequado devido à existência de valores de CBR muito inferiores à média de valores do trecho, pontuais e isolados. Assim, a partir da série de 120 valores de CBR foram criadas e testadas amostras de $60,40,20,10,8,6,5,4$ e 3 valores. Foi também utilizado o agrupamento pelo 'Método das Diferenças Acumuladas'. Na sequência, a todas as amostras obtidas foram introduzidos de um a doze valores inferiores ao menor valor da série original, para então analisar-se o comportamento das curvas de valores representativos.

Uma vez analisadas todas as composições, conclui-se que o método mais apropriado segundo a intenção desta pesquisa é aquele proposto pelo DNIT. Para os principais métodos de determinação do valor característico foram executados o dimensionamento pelo Critério do CBR e a relação de custos de construção. A comparação entre os resultados obtidos confirma a importância deste estudo.

\section{Agradecimentos}

Agradeço ao professor e orientador da presente pesquisa, Dr. Cassio Eduardo Lima de Paiva, por, ao longo de todas as etapas de pesquisa, oferecer sua experiência e conhecimento para o meu melhor entendimento.

\footnotetext{
${ }^{1}$ Balbo, J. T.; Pavimentação Asfáltica; São Paulo; Oficina de Textos; 2007.
} 